University of Nebraska - Lincoln

DigitalCommons@University of Nebraska - Lincoln

USDA National Wildlife Research Center - Staff Publications
U.S. Department of Agriculture: Animal and Plant Health Inspection Service

2016

Repellent application strategy for wild rodents and cottontail rabbits

\author{
Scott J. Werner \\ USDA National Wildlife Research Center, scott.j.werner@aphis.usda.gov \\ Shelagh T. DeLiberto \\ USDA/APHIS/WS National Wildlife Research Center, shelagh.t.deliberto@usda.gov \\ Roger A. Baldwin \\ University of California, Davis \\ Gary W. Witmer \\ USDA-APHIS-Wildlife Services, gary.w.witmer@usda.gov
}

Follow this and additional works at: https://digitalcommons.unl.edu/icwdm_usdanwrc

Part of the Life Sciences Commons

Werner, Scott J.; DeLiberto, Shelagh T.; Baldwin, Roger A.; and Witmer, Gary W., "Repellent application strategy for wild rodents and cottontail rabbits" (2016). USDA National Wildlife Research Center - Staff Publications. 1874.

https://digitalcommons.unl.edu/icwdm_usdanwrc/1874

This Article is brought to you for free and open access by the U.S. Department of Agriculture: Animal and Plant Health Inspection Service at DigitalCommons@University of Nebraska - Lincoln. It has been accepted for inclusion in USDA National Wildlife Research Center - Staff Publications by an authorized administrator of DigitalCommons@University of Nebraska - Lincoln. 


\title{
Repellent application strategy for wild rodents and cottontail rabbits
}

\author{
Scott J. Werner ${ }^{a}, *$, Shelagh T. DeLiberto ${ }^{a}$, Roger A. Baldwin ${ }^{b}$, Gary W. Witmer ${ }^{a}$ \\ a United States Department of Agriculture, Animal and Plant Health Inspection Service, Wildlife Services, National Wildlife Research Center, 4101 LaPorte \\ Avenue, Fort Collins, CO 80521-2154, USA \\ b Department of Wildlife, Fish, and Conservation Biology, One Shields Avenue, University of California, Davis, CA 95616, USA
}

\section{A R T I C L E I N F O}

\section{Article history:}

Received 4 February 2016

Received in revised form 17 October 2016

Accepted 19 October 2016

Available online 26 October 2016

\section{Keywords:}

Chemical repellent

Feeding behavior

Microtus californicus

Peromyscus maniculatus

Sylvilagus audubonii

Urocitellus richardsonii

\begin{abstract}
A B S T R A C T
Effective chemical repellents and repellent application strategies are needed to manage damages caused by wild rodents and rabbits to agricultural resources. For the purpose of comparatively investigating the behavioral response of wild rodents and rabbits to a chemical repellent, we experimentally evaluated the concentration-response relationship of an anthraquinone-based repellent in California voles (Microtus californicus Peale), Richardson's ground squirrels (Urocitellus richardsonii Sabine), deer mice (Peromyscus maniculatus Wagner) and cottontail rabbits (Sylvilagus audubonii Baird) in captivity. We observed 52-56\% feeding repellency for whole oats treated with $10,800 \mathrm{ppm}$ anthraquinone or 18,500 ppm anthraquinone in mice and squirrels, and $84-85 \%$ repellency for oats treated with 18,300 ppm anthraquinone or 19,600 ppm anthraquinone in voles and rabbits, respectively. In addition to providing the negative postingestive consequences necessary for conditioned food avoidance, the anthraquinonebased repellent also absorbs ultraviolet (UV) wavelengths that are visible to most wild birds. For the purpose of developing a repellent application strategy to modify the behavior of vertebrate pests, we therefore conducted a conditioned avoidance experiment by offering repellent- and UV-treated food to California voles in a subsequent behavioral assay. Relative to unconditioned test subjects $(P=0.3161)$, voles conditioned with the UV, postingestive repellent subsequently avoided whole oats treated only with an UV cue $(P=0.0109)$. These behavioral responses to anthraquinone-based repellents and UV feeding cues can be exploited as a repellent application strategy for wild mammals. We discuss potential applications of preplant seed treatments and surface treatments that include postingestive repellents and related visual cues for the protection of agricultural resources associated with mammalian depredation. Published by Elsevier B.V.
\end{abstract}

\section{Introduction}

The opportunistic feeding behavior and fecundity of some wild rodents and rabbits cause economic losses annually to world-wide agricultural production (Gebhardt et al., 2011; Jacob and Tkadlec, 2010; Johnson and Timm, 1987; Pelz, 2003; Salmon, 2008; Witmer and Singleton, 2010). For example, voles (Microtus spp. Schrank and Arvicola spp. La Cépède) are known to cause damage in the United States of America and Europe to agricultural crops such as alfalfa, peas and wheat, and reforestation efforts (Baldwin et al., 2014; Giusti, 2004; Jacob and Tkadlec, 2010; Sullivan and Sullivan, 2008; Witmer et al., 2007). Ground squirrels (Spermophilus spp. Cuvier) cause millions of dollars of damage to alfalfa production in the western United States and Canada (Johnson-Nistler et al., 2005; Proulx, 2010). Ground squirrels caused \$17.9-23.9 million

\footnotetext{
* Corresponding author.

E-mail address: Scott.J.Werner@aphis.usda.gov (S.J. Werner).
}

in crop losses and \$11.9-17.9 million (dollars projected for 2016 valuation) in physical damages to materials such as structures, levees and earthen dams as well as damages to nut crops, tree fruits and rangeland forage (Baldwin et al., 2013; Marsh, 1998). Deer mice (Peromyscus spp. Gloger) cause damage to corn, almonds, avocados, citrus, pomegranate and sugar beet crops (Pearson et al., 2000; Witmer and Moulton, 2012). Cottontail rabbits (Sylvilagus floridanus Allen) damage tree seedlings, shrubs, hay, soybean and rangeland forage (Dugger et al., 2004; Johnson and Timm, 1987).

Agricultural depredation caused by wild rodents and rabbits is a persistent problem with few cost-effective solutions. Methods to alleviate damage caused by wild rodents and rabbits include behavioral applications (e.g. physical exclusion, chemical repellents) and lethal removal. The need for effective solutions to mammal depredation remains despite prior evaluations of numerous chemical repellents (Agnello et al., 2014; Baldwin et al., 2014; Gurney et al., 1996; Nolte and Barnett, 2000; Nolte et al., 1993; Sutherland, 2003; Williams and Short, 2014). The effectiveness and commercial development of wildlife repellents are dependent upon the repellent's 
efficacy under field conditions, cost relative to expected damages of unprotected resources, environmental impacts, and food and feed safety (Werner et al., 2009). Thus, data regarding efficacy, chemical residues and application strategies are presently needed for the development of non-lethal repellents and the protection of agricultural resources from wild rodents and rabbits.

Although anthraquinone is a naturally-occurring compound that was identified as a promising avian repellent in the early 1940s (Heckmanns and Meisenheimer, 1944), an anthraquinonebased seed treatment (AV-1011; Arkion ${ }^{\circledR}$ Life Sciences, New Castle, DE, USA) was first registered by the United States Environmental Protection Agency for the protection of newly-planted rice in January 2016. Anthraquinone has been used to effectively repel blackbirds (Avery et al., 1997, 1998; Carlson et al., 2013; Cummings et al., 2002a,b, 2011; Neff and Meanley, 1957; Werner et al., 2009, 2011a, 2014b,c), Canada geese (Branta canadensis Linnaeus; Blackwell et al., 1999; Dolbeer et al., 1998; Werner et al., 2009), sandhill cranes (Grus canadensis Linnaeus; Blackwell et al., 2001), ring-necked pheasants (Phasianus colchicus Linnaeus; Werner et al., 2009), European starlings (Sturnus vulgaris Linnaeus; Tupper et al., 2014), wild turkeys (Meleagris gallopavo Linnaeus; Werner et al., 2014a), horned larks (Eremophila alpestris Linnaeus), great-tailed grackles (Quiscalus mexicanus Gmelin) and American crows (Corvus brachyrhynchos Brehm; Werner et al., 2015).

Relatively few studies, however, have evaluated anthraquinone as a mammalian repellent. Santilli et al. (2005) discovered that wild boar (Sus scrofa Linnaeus) consumed $86.5 \%$ less corn treated with $0.64 \%$ anthraquinone than untreated corn. Werner et al. (2011b) observed $24-37 \%$ repellency in black-tailed prairie dogs (Cynomys ludovicianus Ord) offered corn seeds treated with $0.5-4.0 \%$ anthraquinone. Cowan et al. (2015) observed an aversion to anthraquinone-treated baits in black rats (Rattus rattus Linnaeus; $0.1 \%$ and $0.25 \%$ anthraquinone) and possums (Trichosurus vulpecula Kerr; $0.25 \%$ anthraquinone). Relative to the consumption of control baits $(0.01-0.03 \%$ cinnamon, green carrots), the consumption of anthraquinone-treated baits was less in brown rats $(R$. norvegicus Berkenhout; $0.04 \%$ and $0.08 \%$ anthraquinone) and no different in possums ( $T$. vulpecula, $0.08 \%$ anthraquinone; Clapperton et al., 2015). Although Hansen et al. (2015) observed that female common voles (M. arvalis Pallas) consumed 47\% less wheat treated with 5\% anthraquinone and chloroform than wheat treated only with chloroform, Hansen et al. (2016a) found no difference in consumption of wheat treated with $15 \%$ anthraquinone and chloroform in male common voles and greater consumption of wheat treated with $15 \%$ anthraquinone and chloroform in male house mice (Mus musculus Linnaeus) relative to wheat treated only with chloroform.

The purposes of this study were to comparatively investigate the behavioral response of wild rodents and rabbits to a chemical repellent, and develop an effective application strategy for the protection of agricultural resources commonly damaged by these wild mammals. Our objectives were to (1) experimentally evaluate the concentration-response relationship of an anthraquinone-based repellent for California voles (M. californicus Peale), Richardson's ground squirrels (Urocitellus richardsonii Sabine), deer mice (P. maniculatus Wagner) and cottontail rabbits (S. audubonii Baird), and (2) develop a repellent application strategy by exploiting the behavioral responses of wild rodents and rabbits to anthraquinone-based repellents and associated visual cues.

Most placental mammals (e.g. wild rodents, rabbits) are dichromatic, having two classes of cone photopigment (i.e. long- and short-wave sensitive visual pigments; David-Gray et al., 2002). The short-wave sensitive (SWS) visual pigments of vertebrate cone photoreceptors are divided into two molecular classes, SWS1 and SWS2. Only the SWS1 class is present in mammals. The SWS1 class has been subdivided into violet-sensitive (VS; peak maximum absorbance, or $\lambda_{\max }=400-430 \mathrm{~nm}$ ) and ultraviolet-sensitive visual pigments (UVS, $\lambda_{\max }<380 \mathrm{~nm}$; Cowing et al., 2002). Although ultraviolet (UV) sensitivity is widespread among animals, UVS visual pigments are considered rare in mammals (Douglas and Jeffery, 2014). Animals without UVS visual pigments, however, will be sensitive to UV wavelengths if they have ocular media that transmit UV wavelengths, as all visual pigments absorb significant amounts of UV if the energy level is sufficient (Douglas and Jeffery, 2014). For the purpose of developing an effective repellent application strategy, we were therefore interested to investigate the conditioned avoidance of UV visual cues subsequent to exposure to an UV, postingestive repellent in California voles.

\section{Concentration-response feeding experiments}

Four concentration-response feeding experiments were conducted at the headquarters of the National Wildlife Research Center (NWRC) in Fort Collins, Colorado (USA). We live-captured 38 California voles adjacent to commercial artichoke fields in California USA, 28 Richardson's ground squirrels within alfalfa fields in Montana, and 34 deer mice and 30 cottontail rabbits adjacent to NWRC-Fort Collins using appropriate Scientific Collection Permits. We used 8-10 test subjects per treatment group (Werner et al., 2009, 2011b) and thus 3-4 concentrations for each of the four tested species based upon the availability of test subjects subsequent to live-captures. The capture, care and use of all test subjects associated with each experiment were approved by the NWRC Animal Care and Use Committee (NWRC Study Protocols QA-2104, QA-2243, QA-2333; S.J. Werner- Study Director).

All test subjects were offered a maintenance diet for at least one week prior to each of the feeding experiments (i.e. quarantine, holding). For the purpose of comparatively investigating the intra- and interspecific efficacy of a chemical repellent, all test subjects were maintained within individual cages throughout the experiments (quarantine, holding, acclimation, pre-test, test). California voles, Richardson's ground squirrels and cottontail rabbits were maintained within visually-isolated, individual cages $(23 \times 41 \times 18-\mathrm{cm}$ cages for voles, $62 \times 50 \times 42$-cm for ground squirrels, $62 \times 50 \times 42$ $\mathrm{cm}$ for rabbits) in an NWRC indoor animal research building. Deer mice were maintained within individual cages $(46 \times 24 \times 19-\mathrm{cm})$ in the NWRC outdoor animal research facility throughout the experiment to reduce the potential exposure of researchers to hantavirus. Free access to water and environmental enrichment were provided to all test subjects throughout the feeding experiments.

An anthraquinone-based repellent (Avipel ${ }^{\circledR}$ Shield, active ingredient: synthetic 9,10-anthraquinone; Arkion ${ }^{\circledR}$ Life Sciences, New Castle, DE, USA) was used for each of the experiments (Werner et al., 2009, 2010, 2011a,b). Seed treatments for all concentrationresponse experiments were formulated by applying aqueous suspensions $(100 \mathrm{ml} / \mathrm{kg})$ to the test diet using a rotating mixer and household spray equipment (Werner et al., 2014a). The test diet for each of the concentration-response feeding experiments was whole oats.

We hypothesized that repellency would be directly related to repellent concentration during our concentration-response experiments. We operationally defined $\geq 80 \%$ repellency as efficacious during our previous laboratory feeding experiments (Werner et al., 2009, 2011a, 2014a,b,c). Thus, we predicted that consumption of efficacious treatments (i.e. threshold repellency) would be $\leq 20 \%$ of average, pre-test consumption during the concentration-response experiments.

For each test group, the dependent measure of our concentration-response experiments was calculated as average test consumption of treated test diet relative to average, pre-test consumption of untreated test diet (i.e. percent repellency). The NWRC Analytical Chemistry Unit used high performance liquid 
chromatography to quantify actual anthraquinone concentrations ( $\pm 10-100 \mathrm{ppm}$ AQ) among our anthraquinone-treated test diets (Werner et al., 2009, 2011a, 2014a,b,c, 2015). We used non-linear regression procedures (SAS v9.1) to analyze percent repellency as a function of actual anthraquinone concentration (ppm). When non-linear relationships were observed for repellency and repellent concentration $(\alpha \leq 0.05)$, we predicted the threshold anthraquinone concentration needed to achieve $80 \%$ feeding repellency. We used descriptive statistics $(\bar{x} \pm$ S.E.M. $)$ to summarize anthraquinone dosage for observed threshold repellency (mg anthraquinone/ $\mathrm{kg}$ body mass [BM]).

\subsection{California vole feeding experiment}

For the purpose of identifying an effective chemical repellent for wild rodents, this experiment involved concentration-response testing of the anthraquinone-based repellent with California voles in captivity. The maintenance diet for California voles included rodent blocks (LabDiet ${ }^{\circledR}$ 5001; Land O'Lakes, St. Louis, MO, USA) and apple slices. Thirty eight California voles (experimentally-naïve) were available for this feeding experiment. All voles acclimated within individual cages for five days (Wednesday-Sunday). During the acclimation period, one food bowl that contained untreated oats (ad libitum) was presented on the north side of each cage at $0800 \mathrm{~h}$, daily.

During the three days subsequent to the acclimation period (Monday-Wednesday), one bowl (30.0 g untreated oats) was presented on the north side of each cage at $0800 \mathrm{~h}$, daily. Daily food consumption (including spillage and desiccation) was measured $( \pm 0.1 \mathrm{~g})$ at approximately $0800 \mathrm{~h}$ on Tuesday-Thursday. Voles were ranked based upon average, pre-test consumption and assigned to one of four test groups at the conclusion of the pre-test ( $n=8-10$ voles per group) such that each group was similarly populated with voles that exhibited high-low daily consumption (Werner et al., 2009, 2010, 2011a,b). We randomly assigned test treatments among groups (i.e. experimental units).

On the day subsequent to the pre-test (Thursday), one bowl ( $30.0 \mathrm{~g}$ anthraquinone-treated oats) was presented on the north side of each cage at $0800 \mathrm{~h}$. Voles in Groups 1-4 received whole oats treated with $0.25 \%, 0.5 \%, 1.0 \%$, or $2.0 \%$ anthraquinone, respectively (target concentrations, wt/wt). Daily food consumption (including spillage and desiccation) was measured at approximately $0800 \mathrm{~h}$ on Friday.

\subsubsection{Results of California vole feeding experiment}

California voles exposed to whole oats treated with $0.25-2.0 \%$ anthraquinone exhibited $24-84 \%$ repellency during the concentration-response experiment (Fig. 1). Actual anthraquinone concentrations from our anthraquinone-treated oats ranged from 2050-18,300 ppm anthraquinone (Fig. 1). Thus, California voles exhibited $84 \%$ repellency for whole oats treated with $18,300 \mathrm{ppm}$ anthraquinone, or $365.0 \pm 103.1 \mathrm{mg}$ anthraquinone $/ \mathrm{kg}$ $\mathrm{BM}$ (mean vole $\mathrm{BM}=38.1 \mathrm{~g}$ ). Vole repellency $(\mathrm{y})$ was a function of anthraquinone concentration (x): $\mathrm{y}=26.828 \ln (\mathrm{x})-174.795$ $\left(r^{2}=0.95, P=0.0267\right)$. We therefore predicted a threshold concentration of $13,400 \mathrm{ppm}$ anthraquinone for California voles offered treated oats.

\subsubsection{Discussion of California vole feeding experiment}

The results of this laboratory efficacy experiment suggest that a threshold concentration of $1.3 \%$ anthraquinone (wt/wt) can effectively repel California voles from treated food. With regard to the non-lethal management of agricultural crop depredation, anthraquinone-based repellents can be applied as preplant seed treatments for the protection of seeds and seedlings, or as foliar applications for the protection of emergent and maturing seedlings.

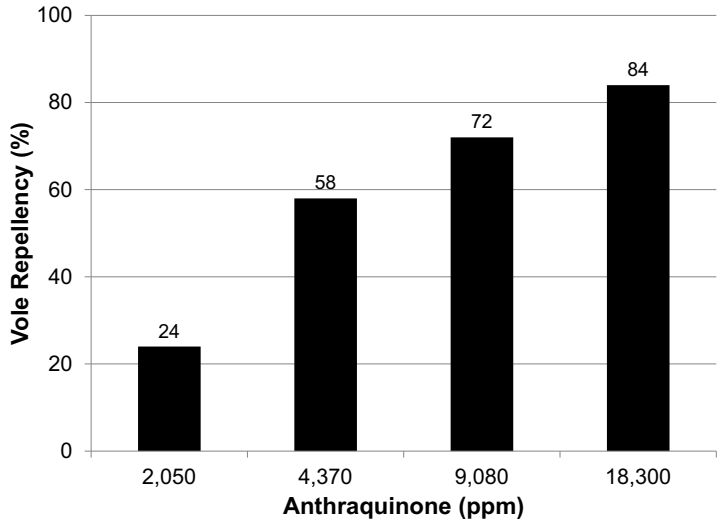

Fig. 1. Mean feeding repellency associated with varying concentrations of an anthraquinone-based repellent (Avipe ${ }^{\circledR}$ Shield; Arkion ${ }^{\circledR}$ Life Sciences, New Castle, DE, USA) offered to California voles (Microtus californicus Peale). Repellency represents test consumption (day 4 ) relative to average, pretreatment consumption (days $1-3$ ) of untreated whole oats ( $n=8-10$ voles per repellent concentration).

We recommend field efficacy testing of anthraquinone-based seed treatments for alfalfa, peas and wheat, and experimental foliar applications of anthraquinone-based repellents within commercial orchards and reforested stands associated with damages caused by California voles.

\subsection{Richardson's ground squirrel feeding experiment}

This experiment involved concentration-response testing of the anthraquinone-based repellent with Richardson's ground squirrels in captivity. The maintenance diet for Richardson's ground squirrels included rodent blocks (LabDiet ${ }^{\circledR} 5001$; Land O'Lakes, St. Louis, MO, USA), apple slices and carrots. We replicated the test procedures of our previous concentration-response experiment with 28 Richardson's ground squirrels (experimentally-naïve) within individual cages (i.e. acclimation, pre-test, test). Test groups $1-3$ ( $n=9-10$ ground squirrels per group) received whole oats treated with $0.5 \%$, $1.0 \%$, or $2.0 \%$ anthraquinone (target concentrations, $\mathrm{wt} / \mathrm{wt}$ ), respectively, during the test.

\subsubsection{Results of Richardson's ground squirrel feeding experiment}

We observed 40-56\% feeding repellency among Richardson's ground squirrels offered whole oats treated with target concentrations of $0.5-2.0 \%$ anthraquinone (Fig. 2). Actual anthraquinone concentrations from our oat seed treatments ranged from $5380-18,500$ ppm anthraquinone (Fig. 2). Ground squirrel repellency was weakly related to actual anthraquinone concentrations $\left(r^{2}=0.95 ; P=0.1458\right)$.

\subsubsection{Discussion of Richardson's ground squirrel feeding experiment}

We observed 56\% repellency for whole oats treated with $18,500 \mathrm{ppm}$ anthraquinone in Richardson's ground squirrels. Although we previously defined $\geq 80 \%$ repellency as efficacious, synergistic repellency can manifest from optimizing the combination of physiologically-relevant sensory cues and targeted postingestive consequences in the formulation of wildlife repellents (Werner et al., 2014b). An efficacious application strategy is needed for foliar and surface applications of chemical repellents for the protection of alfalfa, structures, levees and earthen dams from damages caused by ground squirrels. 


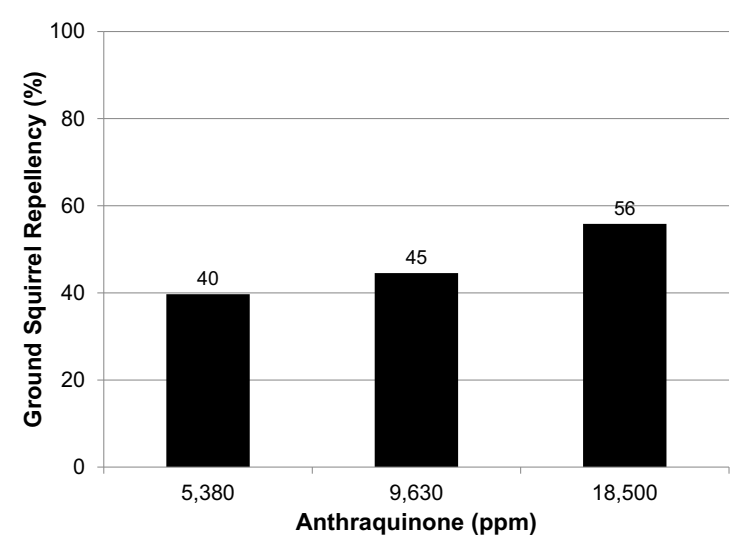

Fig. 2. Mean feeding repellency associated with varying concentrations of an anthraquinone-based repellent (Avipel ${ }^{\circledR}$ Shield; Arkion ${ }^{\circledR}$ Life Sciences, New Castle, $\mathrm{DE}, \mathrm{USA}$ ) offered to Richardson's ground squirrels (Urocitellus richardsonii Sabine). Repellency represents test consumption (day 4) relative to average, pretreatment consumption (days $1-3)$ of untreated whole oats $(n=9-10$ ground squirrels per repellent concentration).

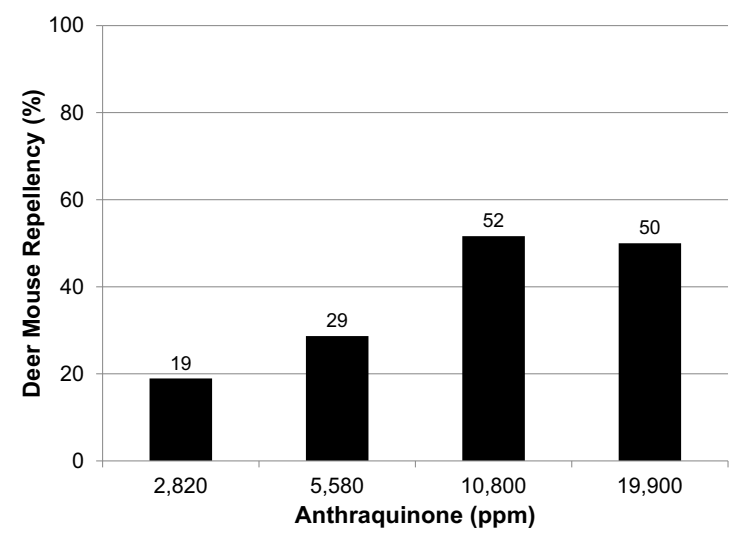

Fig. 3. Mean feeding repellency associated with varying concentrations of an anthraquinone-based repellent (Avipel ${ }^{\circledR}$ Shield; Arkion ${ }^{\circledR}$ Life Sciences, New Castle, DE, USA) offered to deer mice (Peromyscus maniculatus Wagner). Repellency represents test consumption (day 4 ) relative to average, pretreatment consumption (days $1-3$ ) of untreated whole oats ( $n=8-9$ mice per repellent concentration).

\subsection{Deer mouse feeding experiment}

This experiment involved concentration-response testing of the anthraquinone-based repellent with deer mice in captivity. The maintenance diet for deer mice included rodent blocks (LabDiet ${ }^{\circledR}$ 5001; Land O'Lakes, St. Louis, MO, USA) and apple slices. We replicated the test procedures of our previous concentration-response experiments with 34 deer mice (experimentally-naïve) within individual cages (i.e. acclimation, pre-test, test). Test groups 1-4 ( $n=8-9$ mice per group) received whole oats treated with $0.25 \%$, $0.5 \%, 1.0 \%$, or $2.0 \%$ anthraquinone (target concentrations, wt $/ \mathrm{wt}$ ), respectively, during the test.

\subsubsection{Results of deer mouse feeding experiment}

Deer mice exposed to whole oats treated with target concentrations of $0.25-2.0 \%$ anthraquinone exhibited $19-52 \%$ repellency during the concentration-response experiment (Fig. 3). Actual anthraquinone concentrations from our oat seed treatments ranged from 2820-19,900 ppm anthraquinone (Fig. 3). Deer mouse repellency was weakly related to actual anthraquinone concentrations $\left(r^{2}=0.89 ; P=0.0580\right)$.

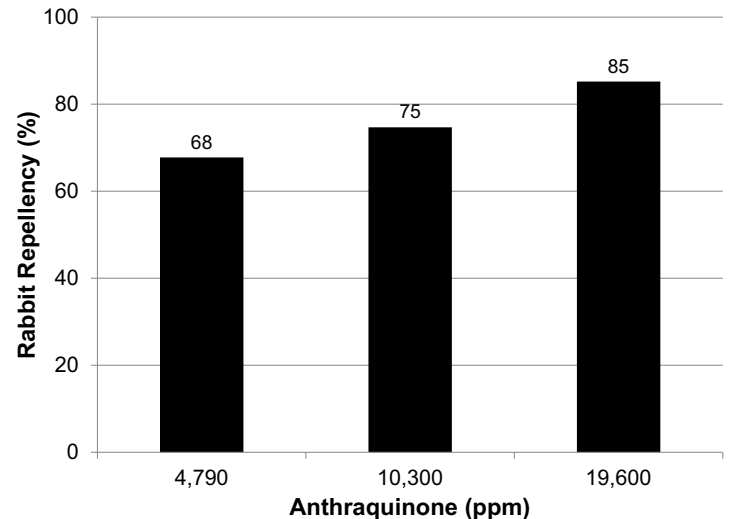

Fig. 4. Mean feeding repellency associated with varying concentrations of an anthraquinone-based repellent (Avipel ${ }^{\circledR}$ Shield; Arkion ${ }^{\circledR}$ Life Sciences, New Castle, DE, USA) offered to cottontail rabbits (Sylvilagus audubonii Baird). Repellency represents test consumption (day 4) relative to average, pretreatment consumption (days $1-3$ ) of untreated whole oats ( $n=10$ rabbits per repellent concentration).

\subsubsection{Discussion of deer mouse feeding experiment}

We observed 52\% repellency for whole oats treated with $10,800 \mathrm{ppm}$ anthraquinone in deer mice. An efficacious application strategy is needed for the development of repellent seed treatments, and the protection of corn seeds and seedlings from wild rodents (e.g. deer mice). Such strategies can also be formulated as foliar repellent applications for the protection of almonds, avocados, citrus, pomegranate and sugar beet crops associated with depredation caused by deer mouse.

\subsection{Cottontail rabbit feeding experiment}

This experiment involved concentration-response testing of the anthraquinone-based repellent with cottontail rabbits in captivity. The maintenance diet for cottontail rabbits included Rabbit Chow $^{\circledR}$ (Purina $^{\circledR}$ Mills, St. Louis, MO, USA), apple slices and alfalfa hay. We replicated the test procedures of our previous concentration-response experiments with 30 cottontail rabbits (experimentally-naïve) within individual cages (i.e. acclimation, pre-test, test). Test groups $1-3$ ( $n=10$ rabbits per group) received whole oats treated with $0.5 \%, 1.0 \%$, or $2.0 \%$ anthraquinone (target concentrations, wt/wt), respectively, during the test.

\subsubsection{Results of cottontail rabbit feeding experiment}

We observed 68-85\% feeding repellency among cottontail rabbits offered whole oats treated with target concentrations of 0.5-2.0\% anthraquinone (Fig. 4). Actual anthraquinone concentrations from our oat seed treatments ranged from 4790-19,600 ppm anthraquinone (Fig. 4). Rabbit repellency was weakly related to actual anthraquinone concentrations $\left(r^{2}=0.99 ; P=0.0757\right)$. We observed 85\% feeding repellency, however, among rabbits offered whole oats treated with $19,600 \mathrm{ppm}$ anthraquinone. Thus, cottontail rabbits were effectively repelled from whole oats treated with a target concentration of $2.0 \%$ anthraquinone (Fig. 4), or $149.9 \pm 28.1 \mathrm{mg}$ anthraquinone $/ \mathrm{kg} \mathrm{BM}$ (mean rabbit $\mathrm{BM}=0.8 \mathrm{~kg}$ ).

\subsubsection{Discussion of cottontail rabbit feeding experiment}

We observed $85 \%$ repellency for whole oats treated with 19,600 ppm anthraquinone in cottontail rabbits. We recommend field efficacy testing of foliar repellent applications for the protection of tree seedlings, shrubs, hay, soybean and rangeland forage associated with damages caused by cottontail rabbits. Field efficacy experiments should include: (1) application strategies that are specifically developed to protect agricultural crops from mammalian depredation; (2) independent field replicates with 
predicted rodent or rabbit damage; (3) varied application rates based upon species-specific threshold concentrations, including untreated controls; (4) pre- and at-harvest analytical chemistry; (5) crop damage measurements; and (6) crop yield measurements (Werner et al., 2011a).

\section{Conditioned avoidance experiment with ultraviolet feeding cue}

Unlike most tested birds (Aidala et al., 2012; Bennett and Cuthill, 1994; Cuthill et al., 2000), most tested mammals do not exhibit UV vision (Honkavaara et al., 2002; Hut et al., 2000; Jacobs, 1992; Jacobs and Yolton, 1971; Jacobs et al., 1991; Tovee, 1995). Anthraquinonebased repellents provide the negative postingestive consequences and a relevant UV feeding cue necessary to condition avoidance of UV-treated food (Werner et al., 2012, 2014a). We therefore investigated conditioned avoidance of UV-treated food subsequent to anthraquinone conditioning in California voles. Seed treatments for the conditioned avoidance experiment were formulated by applying aqueous suspensions $(60 \mathrm{ml} / \mathrm{kg})$ to the test diet using a rotating mixer and household spray equipment (Werner et al., 2012, 2014b).

\subsection{Materials and methods}

Sixteen California voles (experimentally naïve) were used for this feeding experiment. The maintenance diet (apple slices and LabDiet ${ }^{\circledR}$ 5001, Land O'Lakes St. Louis, MO, USA) and water was again provided to all voles within individual cages, daily. The anthraquinone-based repellent (Avipel ${ }^{\circledR}$ Shield; Arkion ${ }^{\circledR}$ Life Sciences, New Castle, DE, USA) and a titanium dioxide feeding cue (Aeroxide ${ }^{\circledR}$ P25; Acros Organics, Fair Lawn, NJ, U.S.A.) were used for the conditioned avoidance feeding experiment (Werner et al., 2012, 2014a,b). A Genesys ${ }^{\mathrm{TM}}$ 2, 336002 spectrophotometer (Thermo Spectronic US, Rochester, NY, USA) was previously used to determine that both the anthraquinone-based repellent and the titanium dioxide feeding cue absorb near UV wavelengths (Werner et al., 2012).

All voles acclimated within individual cages for five days (Wednesday-Sunday; Week 1). Two food bowls (east and west side of each cage) of unadulterated oats were provided throughout the acclimation period. Two food bowls (unadulterated oats on east and west sides of cage) were presented at approximately $0800 \mathrm{~h}$, daily for two days subsequent to acclimation (Monday and Tuesday; Week 2). We ranked cages based upon pre-test consumption, assigned cages to one of two groups, and randomly assigned treatments between groups at the completion of the pre-test.

Two food bowls (east and west side of cage) were presented at approximately $0800 \mathrm{~h}$, daily for two days subsequent to the pre-test (Wednesday and Thursday; Week 2). For the purpose of behavioral conditioning with the UV-absorbent, postingestive repellent, we exposed all voles in the conditioned group (Group $1 ; n=8$ ) to oats treated with $0.25 \%$ anthraquinone (target concentration, wt/wt) in both food bowls. We exposed all voles in the unconditioned group (Group $2 ; n=8$ ) to unadulterated oats in both food bowls. We provided two food bowls of the maintenance diet from approximately 0930 h on Friday (Week 2) through 0800 h on Monday (Week 3 ) to all test subjects.

Two food bowls were presented at approximately $0800 \mathrm{~h}$, daily for four test days (Monday-Thursday; Week 3). For the purpose of preference testing with the UV-absorbent feeding cue subsequent to behavioral conditioning, Groups 1 and 2 received oats treated with $0.2 \%$ of the UV cue in one bowl, and untreated oats in the alternate bowl, daily. We randomly located UV-treated oats on the first test day (i.e. east or west side of cage) and thereafter alternated daily throughout the test such that UV-treated and untreated oats

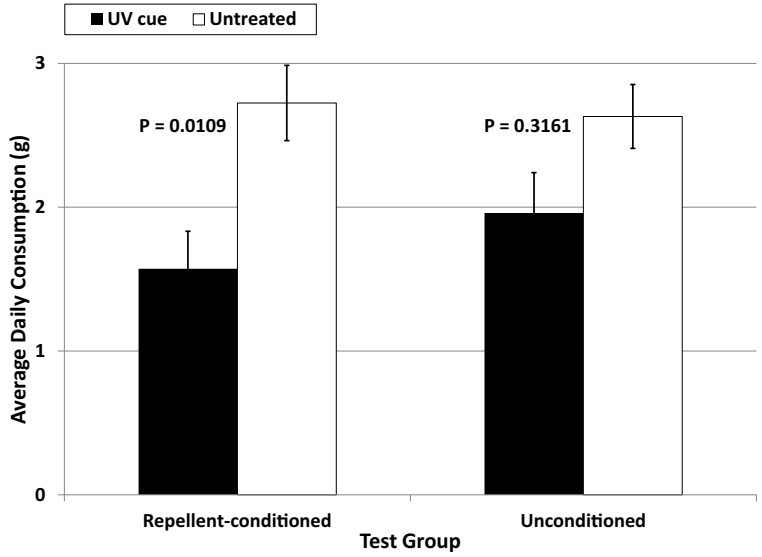

Fig. 5. Mean consumption ( \pm S.E.M.) of whole oats offered to California voles (Microtus californicus Peale; $n=8$ per test group). Voles were offered untreated whole oats and those treated with $0.2 \%$ of an UV feeding cue (active ingredient: titanium dioxide; Evonik Goldschmidt Corporation) throughout the four-day test. The repellent-conditioned test group was exposed to an UV, postingestive repellent prior to the test.

were each offered twice on the east and west side of each cage. We independently measured oat consumption in east and west food bowls in each cage throughout the test (i.e. approximately $0800 \mathrm{~h}$, Tuesday-Friday; Week 3).

The dependent measure of our conditioned avoidance experiment was average (i.e. daily) test consumption of treated and untreated food. After conducting Levene's test for equal variances $(\alpha=0.05)$ and affirmatively inspecting the normality of residuals, consumption data were subjected to a Welch's analysis of variance. The group-by-treatment interaction was analyzed using a general linear model (SAS v9.1). We used Tukey-Kramer multiple comparisons to separate the means of the significant interaction $(\alpha=0.05)$. Descriptive statistics ( $\bar{x} \pm$ S.E.M.) were used to summarize consumption of treated and untreated food throughout the conditioned avoidance experiment.

\subsection{Results of conditioned avoidance experiment}

The two test groups consumed different amounts of UV-treated and untreated food during the four-day test $\left(F_{3,67}=4.48, P=0.0063\right)$. Relative to the consumption of untreated oats, voles conditioned with the UV-absorbent, postingestive repellent consumed fewer oats treated only with the UV-absorbent cue throughout the test (i.e. repellent-conditioned, Fig. 5). The repellent-conditioned group consumed an average of $1.6 \pm 0.3 \mathrm{~g}$ of UV-treated whole oats and $2.7 \pm 0.3 \mathrm{~g}$ of untreated oats per day, throughout the test (TukeyKramer $P=0.0109$ ).

In contrast, unconditioned voles consumed similar amounts of UV-treated oats and untreated oats throughout the test (Fig. 5). The unconditioned group consumed an average of $2.0 \pm 0.3 \mathrm{~g}$ of UV-treated whole oats and $2.6 \pm 0.2 \mathrm{~g}$ of untreated oats per day, throughout the test (Tukey-Kramer $P=0.3161$ ). Thus, without prior conditioning with the UV-absorbent, postingestive repellent, the UV-absorbent cue was not itself aversive to California voles. Moreover, although California voles are not maximally sensitive to UV wavelengths, voles conditioned with the UV-absorbent, postingestive repellent subsequently consumed less food treated only with the UV-absorbent cue.

\subsection{Discussion of conditioned avoidance experiment}

Because California voles consumed less of the test diet treated only with the UV-absorbent feeding cue subsequent to condition- 
ing with the UV-absorbent, postingestive repellent (i.e. relative to the unconditioned control group; Fig. 5), we observed cueconsequence specificity (Domjan, 1985) for an UV visual cue and a postingestive repellent in a dichromatic rodent. Thus, similar to blackbirds (Werner and Provenza, 2011), California voles cognitively associate pre- and postingestive consequences with visual cues, and reliably integrate visual and gustatory experience with postingestive consequences to procure nutrients and avoid toxins. These visual cues include UV-absorbent and UV-reflective cues for mammalian feeding behavior. The behavioral responses of this study can be exploited as a repellent application strategy for the protection of agricultural resources. This application strategy comprises a postingestive repellent and a feeding cue with visual characteristics sufficiently similar to the repellent such that the repellent concentration can be decreased (i.e. to include $0 \%$ of the chemical repellent subsequent to repellent exposure, Fig. 5) whilst maintaining or synergistically increasing repellent efficacy (Werner et al., 2014b).

The repellent application strategy described herein (i.e. UV, postingestive repellent and associated UV visual cue) has implications for several wild rodents and rabbits. Although the spectral sensitivity function peaks at $520 \mathrm{~nm}$ in California ground squirrels (i.e. VS visual pigments; Otospermophilus beecheyi; Anderson and Jacobs, 1972), the lens of Mexican ground squirrels (Ictidomys mexicanus) exhibits $\lambda_{\max }$ of $265-370 \mathrm{~nm}$ (i.e. UVS visual pigments; Cooper and Robson, 1969). In Richardson's ground squirrels, 50\% of incident illumination is transmitted at $462 \mathrm{~nm}$ and $0.6 \%$ of light from 315 to $400 \mathrm{~nm}$ is transmitted by the lens (Douglas and Jeffery, 2014). Although shortwave sensitive cones (S) constitute only $5-15 \%$ of the cones in deer mice, partial sequencing of the $S$ opsin gene suggested UV sensitivity of the $\mathrm{S}$ cone visual pigment (Arbogast et al., 2013). In house mice, 50\% of incident illumination is transmitted at $313-337 \mathrm{~nm}$ and $81.7 \%$ of light from 315 to $400 \mathrm{~nm}$ is transmitted by the lens (Douglas and Jeffery, 2014). The maximum optical transmittance (i.e. 94-96\%) in albino rabbits was found between 630 and $730 \mathrm{~nm}$; transmittance decreased to $50 \%$ at $400 \mathrm{~nm}$ and $<1 \%$ at $380 \mathrm{~nm}$ (Algvere et al., 1993). In rabbits (Oryctolagus cuniculus Linnaeus), 50\% of incident illumination is transmitted at $392 \mathrm{~nm}$ and $12.7 \%$ of light from 315 to $400 \mathrm{~nm}$ is transmitted by the lens (Douglas and Jeffery, 2014). Thus, supplemental laboratory and field efficacy testing is recommended for the comparative evaluation and commercial development (e.g. pricing of optimized formulations) of a repellent application strategy comprising an UV, postingestive repellent and an associated UV feeding cue for wild rodents and rabbits.

\section{General discussion}

We observed 52-56\% feeding repellency for whole oats treated with $10,800 \mathrm{ppm}$ anthraquinone or $18,500 \mathrm{ppm}$ anthraquinone in mice and squirrels, and $84-85 \%$ repellency for oats treated with $18,300 \mathrm{ppm}$ anthraquinone or $19,600 \mathrm{ppm}$ anthraquinone in voles and rabbits, respectively. We therefore observed considerable interspecific variation in the feeding behavior of these wild mammals offered food treated with the anthraquinonebased repellent. Similarly, we predicted a threshold concentration of $1450-1475 \mathrm{ppm}$ anthraquinone for Canada geese and redwinged blackbirds, $5200 \mathrm{ppm}$ anthraquinone for American crows, $9200 \mathrm{ppm}$ anthraquinone for common grackles (Quiscalus quiscula Linnaeus) and $10,450 \mathrm{ppm}$ anthraquinone for ring-necked pheasants (Werner et al., 2009, 2011a, 2015). Thus, anthraquinone repellency is not inversely proportional to the body mass of the target animal and considerable interspecific variation exists for anthraquinone among tested mammals and birds. We therefore recommend species-specific efficacy testing for each target animal under laboratory and field conditions.

Relative to unconditioned test subjects, voles conditioned with the UV, postingestive repellent subsequently avoided whole oats treated only with an UV cue. Similarly, red-winged blackbirds conditioned with the UV, postingestive repellent subsequently avoided UV-treated food relative to unconditioned blackbirds (Werner et al., 2012). This ultraviolet strategy for repellent applications was recently developed for wild birds associated with agricultural crop depredation (Werner, 2015). Relative to the repellency of food treated only with the anthraquinone-based repellent, synergistic repellency (i.e. $45-115 \%$ increase) was observed when $0.2 \%$ of the UV feeding cue was combined with $0.02 \%$ or $0.035 \%$ anthraquinone (wt/wt; Werner et al., 2014b). This ultraviolet strategy for repellent applications is presently being developed for the management of damages caused by wild rodents and rabbits to plant and animal agriculture.

Among the wild mammals that we have experimentally offered food treated with $0.25-2 \%$ anthraquinone (wt/wt), the ranked efficacy of anthraquinone-based repellents in order of high-low repellency was cottontail rabbits (68-85\% repellency), California voles (24-84\% repellency), Richardson's ground squirrels (40-56\% repellency), deer mice (19-52\% repellency) and black-tailed prairie dogs (24-37\% repellency; Werner et al., 2011b). Interestingly, the transmittance of UVA wavelengths $(315-400 \mathrm{~nm}$ ) through the ocular media was estimated to be $13 \%, 0.6 \%$ and $0 \%$ in European rabbits (Oryctolagus cuniculus Linnaeus), Richardson's ground squirrels and black-tailed prairie dogs, respectively (Douglas and Jeffery, 2014). Thus, the efficacy of this UV, postingestive repellent is directly proportional to the known transmittance of UVA wavelengths in these wild mammals. We therefore recommend additional research for the development of non-lethal, UV repellent application strategies for wild mammals associated with human-wildlife conflicts.

Because inconsistent success has been observed among rodent repellent trials conducted under laboratory and field conditions, a progression of efficacy experiments (i.e. cage, then enclosure, then field studies) has been recommended for the reliable measurement of repellency and the successful development of non-lethal wildlife repellents (Hansen et al., 2016b). We recommend field enclosure experiments to further evaluate anthraquinone-based repellents and ultraviolet application strategies. The results of our current study will enable the design of supplemental field efficacy experiments and the development of non-lethal repellents for wild rodents, rabbits and other wildlife associated with human-wildlife conflicts.

\section{Conclusion}

This study provided a novel investigation of an anthraquinonebased repellent and related visual cues for wild rodents and rabbits associated with damages to agricultural resources. We observed $52-56 \%$ feeding repellency for whole oats treated with $10,800 \mathrm{ppm}$ anthraquinone or $18,500 \mathrm{ppm}$ anthraquinone in deer mice and Richardson's squirrels, and $84-85 \%$ repellency for oats treated with $18,300 \mathrm{ppm}$ anthraquinone or $19,600 \mathrm{ppm}$ anthraquinone in California voles and cottontail rabbits, respectively. Relative to unconditioned test subjects, voles conditioned with the UV, postingestive repellent subsequently avoided whole oats treated only with an UV cue. Thus, California voles cognitively associate pre- and postingestive consequences with visual cues, and reliably integrate visual and gustatory experience with postingestive consequences to procure nutrients and avoid toxins. These behavioral responses to anthraquinone-based repellents and UV feeding cues can be exploited as a repellent application strategy for the non-lethal management of agricultural depredation caused by 
wild mammals. This application strategy comprises a postingestive repellent and a feeding cue with visual characteristics sufficiently similar to the repellent such that the repellent concentration can be decreased whilst maintaining or increasing repellent efficacy.

\section{Acknowledgements}

This research was supported in part by California Department of Food and Agriculture's Vertebrate Pest Control Research Advisory Committee (Sacramento, CA, USA). Our feeding experiments were conducted with Avipel ${ }^{\circledR}$ Shield repellent (Arkion ${ }^{\circledR}$ Life Sciences, New Castle, DE, USA) and a titanium dioxide feeding cue (Aeroxide ${ }^{\circledR}$ P25; Acros Organics, Fair Lawn, NJ, U.S.A.). Corporate collaborations do not imply endorsement by the United States Department of Agriculture. We are grateful for the assistance provided by California artichoke growers during the live-capture of California voles. The NWRC Analytical Chemistry Unit performed anthraquinone residue analyses for our concentration-response feeding experiments. We also thank the National Wildlife Research Center animal care staff that provided daily care of all test subjects throughout quarantine and holding for each experiment.

\section{References}

Agnello, A.M., Kain, D.P., Gardner, J., Curtis, P.D., Ashdown, M.L., Hoffmann, M.P. 2014. Novel barriers to prevent dogwood borer (Lepidoptera: Sesiidae) and rodent damage in apple plantings. J. Econ. Entomol. 107, 1179-1186.

Aidala, Z., Huynen, L., Brennan, P.L.R., Musser, J., Fidler, A., Chong, N., Machovsky Capuska, G.E., Anderson, M.G., Talaba, A., Lambert, D., Hauber, M.E., 2012. Ultraviolet visual sensitivity in three avian lineages: paleognaths, parrots, and passerines. J. Comp. Physiol. A 198, 495-510.

Algvere, P.V., Torstensson, P.L., Tengroth, B.M., 1993. Light transmittance ofocular media in living rabbit eyes. Invest. Ophthal. Vis. Sci. 34, 349-354.

Anderson, D.H., Jacobs, G.H., 1972. Color vision and visual sensitivity in the Californiaground squirrel (Citellus beecheyi). Vision Res. 12, 1995-2004.

Arbogast, P., Glosmann, M., Peichl, L., 2013. Retinal cone photoreceptors of the deer mouse Peromyscus maniculatus: development, topography, opsin expression and spectral tuning. PLoS One 8 (11), e80910.

Avery, M.L., Humphrey, J.S., Decker, D.G., 1997. Feeding deterrence of anthraquinone, anthracene, and anthrone to rice-eating birds. J. Wildl. Manage. 61, 1359-1365.

Avery, M.L., Humphrey, J.S., Primus, T.M., Decker, D.G., McGrane, A.P., 1998. Anthraquinone protects rice seed from birds. Crop Prot. 17, 225-230.

Baldwin, R.A., Salmon, T.P., Schmidt, R.H., Timm, R.M., 2013. Wildlife pests of California agriculture: regional variability and subsequent impacts on management. Crop Prot. 46, 29-37.

Baldwin, R.A., Salmon, T.P., Schmidt, R.H., Timm, R.M., 2014. Perceived damage and areas of needed research for wildlife pests of California agriculture. Int. Zool. 9 265-279.

Bennett, A.T.D., Cuthill, I.C., 1994. Ultraviolet vision in birds: what is its function? Vision Res. 34, 1471-1478

Blackwell, B.F., Seamans, T.W., Dolbeer, R.A., 1999. Plant growth regulator (Stronghold ${ }^{\mathrm{TM}}$ ) enhances repellency of anthraquinone formulation (Flight Control $^{\mathrm{TM}}$ ) to Canada geese. J. Wildl. Manage. 63, 1336-1343.

Blackwell, B.F., Helon, D.A., Dolbeer, R.A., 2001. Repelling sandhill cranes from corn: whole-kernel experiments with captive birds. Crop Prot. 20, 65-68.

Carlson, J.C., Tupper, S.K., Werner, S.J., Pettit, S.E., Santer, M.M., Linz, G.M., 2013. Laboratory efficacy of an anthraquinone-based repellent for reducing bird damage to ripening corn. Appl. Anim. Behav. Sci. 145, 26-31.

Clapperton, B.K., Day, T.D., Morgan, D.K.J., Huddart, F., Cox, N., Matthews, L.R., 2015. Palatability and efficacy to possums and rats of pest control baits containing bird repellents. NZ J. Zool. 42, 104-118.

Cooper, G.F., Robson, J.G., 1969. The yellow colour of the lens of the grey squirrel (Sciurus carolinensis leucotis). J. Physiol. 203, 403-410.

Cowan, P., Brown, S., Forrester, G., Booth, L., Crowell, M., 2015. Bird-repellent effects on bait efficacy for control of invasive mammal pests. Pest Manage. Sci. 71, 1075-1081.

Cowing, J.A., Poopalasundaram, S., Wilkie, S.E., Robinson, P.R., Bowmaker, J.K., Hunt, D.M., 2002. The molecular mechanism for the spectral shifts between vertebrate ultraviolet-and violet-sensitive cone visual pigments. J. Biochem. 367, 129-135.

Cummings, J.L., Avery, M.L., Mathre, O., Wilson, E.A., York, D.L., Engeman, R.M., Pochop, P.A., Davis Jr., J.E., 2002a. Field evaluation of Flight Control ${ }^{\mathrm{TM}}$ to reduce blackbird damage to newly planted rice. Wildl. Soc. Bull. 30, 816-820.

Cummings, J.L., Pochop, P.A., Engeman, R.M., Davis Jr., J.E., Primus, T.M., 2002b. Evaluation of Flight Control ${ }^{\circledR}$ to reduce blackbird damage to newly planted rice in Louisiana. Int. Biodeterior. Biodegrad. 49, 169-173.
Cummings, J.L., Byrd, R.W., Eddleman, W.R., Engeman, R.M., Tupper, S.K., 2011 Effectiveness of AV- $1011^{\circledR}$ to reduce damage to drill-planted rice from blackbirds. J. Wildl. Manage. 75, 353-356.

Cuthill, I.C., Partridge, J.C., Bennett, A.T.D., Church, S.C., Hart, N.S., Hunt, S., 2000. Ultraviolet vision in birds. Adv. Study Behav. 29, 159-214.

David-Gray, Z.K., Bellingham, J., Munoz, M., Avivi, A., Nevo, E., Foster, R.G., 2002. Adaptive loss of ultraviolet-sensitive/violet-sensitive (UVS/VS) cone opsin in the blind mole rat (Spalax ehrenbergi). Eur. J. Neurosci. 16, 1186-1194.

Dolbeer, R.A., Seamans, T.W., Blackwell, B.F., Belant, J.L., 1998. Anthraquinone formulation (Flight Control ${ }^{\mathrm{TM}}$ ) shows promise as avian feeding repellent. J. Wildl. Manage. 62, 1558-1564.

Domjan, M., 1985. Cue-consequence specificity and long-delay learning revisited. Ann. N. Y. Acad. Sci. 443, 54-66.

Douglas, R.H., Jeffery, G., 2014. The spectral transmission of ocular media suggests ultraviolet sensitivity is widespread among mammals. Proc. R. Soc. B 281 20132995

Dugger, S., Dey, D.C., Millspaugh, J.J., 2004. Vegetation cover affects mammal herbivory on planted oaks and success of reforesting Missouri River bottomland fields. In: Connor, K.R. (Ed.), Proc. Of the 12th Biennial Southern Silvicultural Research Conference. Gen. Tech. Rep. SRS-71. Asheville, NC: U.S. Dept. of Agric., Forest Service, Southern Research Station, p. 2004.

Gebhardt, K., Anderson, A.M., Kirkpatrick, K.N., Shwiff, S.A., 2011. A review and synthesis of bird and rodent damage estimates to select California crops. Crop Prot. 30, 1109-1116.

Giusti, G.A. 2004. Assessment and monitoring of California vole (Microtus californicus) feeding damage to a coastal redwood (Sequoia sempervirens) restoration project. Proc. Vertebr. Pest Conf. 21, 169-173.

Gurney, J.E., Watkins, R.W., Gill, E.L., Cowan, D.P., 1996. Non-lethal mouse repellents: evaluation of cinnamamide as a repellent against commensal and field rodents. Appl. Anim. Behav. Sci. 49, 353-363.

Hansen, S.C., Stolter, C., Jacob, J., 2015. The smell to repel: the effect of odors on the feeding behavior of female rodents. Crop Prot. 78, 270-276.

Hansen, S.C., Stolter, C., Jacob, J., 2016a. Effect of plant secondary metabolites on feeding behavior of microtine and arvicoline rodent species. J. Pest Sci. 89, 955-963.

Hansen, S.C., Stolter, C., Imholt, C., Jacob, J., 2016b. Plant secondary metabolites as rodent repellents: a systematic review. J. Chem. Ecol., http://dx.doi.org/10. $1007 /$ s10886-016-0760-5 (in press).

Heckmanns, F., Meisenheimer, M., 1944. Protection of seeds against birds. Patent 2, 339, 335. U.S. Patent Office, Washington, D.C

Honkavaara, J., Koivula, M., Korpimaki, E., Siitari, H., Viitala, J., 2002. Ultraviolet vision and foraging in terrestrial vertebrates. Oikos 98, 505-511.

Hut, R.A., Scheper, A., Daan, S., 2000. Can the circadian system of a diurnal and nocturnal rodent entrain to ultraviolet light? J. Comp. Physiol. A 186, 707-715.

Jacob, J., Tkadlec, E., 2010. Rodent outbreaks in Europe: dynamics and damage. In: Singleton, G.R., Belmain, S.R., Brown, P.R., Hardy, B. (Eds.), Rodent Outbreaks: Ecology and Impacts. Los Bacos, pp. 207-224.

Jacobs, G.H., Yolton, R.L., 1971. Visual sensitivity and color vision in ground squirrels. Vision Res. 11, 511-537.

Jacobs, G.H., Neitz, J., Deegan II, J.F., 1991. Retinal receptors in rodents maximally sensitive to ultraviolet light. Nature 353, 655-656.

Jacobs, G.H., 1992. Ultraviolet vision in vertebrates. Am. Zool. 32, 544-554.

Johnson, R.J., Timm, R.M., 1987. Wildlife damage to agriculture in Nebraska: a preliminary cost assessment. Proc. East. Wildl. Damage Control Conf. 3, 57-65.

Johnson-Nistler, C.M., Knight, J.E., Cash, S.D., 2005. Considerations related to Richardson's ground squirrel control in Montana. Agron. J. 97, 1460-1464.

Marsh, R.E., 1998. Historical review of ground squirrel crop damage in California. Int. Biodeterior. Biodegrad. 42, 93-99.

Neff, J.A., Meanley, B., 1957. Research on Bird Repellents: Bird Repellent Studies in the Eastern Arkansas Rice Fields. Wildl. Res, Lab., Denver, CO, 21 pp.

Nolte, D.L., Barnett, J.P., 2000. A repellent to reduce mouse damage to longleaf pine seed. Int. Biodeterior. Biodegred. 45, 169-174.

Nolte, D.L., Mason, J.R., Clark, L., 1993. Avoidance of bird repellents by mice (Mus musculus). J. Chem. Ecol. 19, 427-432.

Pearson, A.B., Gorenzel, W.P., Salmon, T.P., 2000. Lesser-known vertebrate pests of almonds in California. Proc. Vertebr. Pest Conf. 19, 365-376.

Pelz, H.J., 2003. Current approaches towards environmentally benign prevention of vole damage in Europe. In: Singleton, G.R., Hinds, L.A., Krebs, C.J., Spratt, D.M. (Eds.), Rats, Mice and People: Rodent Biology and Management. Australian Centre for International Agricultural Research (ACIAR), Canberra, pp. 233-237.

Proulx, G., 2010. Factors contributing to the outbreak of Richardson's ground squirrel populations in the Canadian prairies. Proc. Vertebr. Pest Conf. 24, 213-217.

Salmon, T.P., 2008. Rodents, rodent control, and food safety. Proc. Vertebr. Pest Conf. 23, 16-19.

Santilli, F., Galardi, L., Russo, C., 2005. Corn appetibility reduction in wild boar (Sus scrofa $L$ : ) in relationship to the use of commercial repellents. Ann. Fac. Med. Vet $58,213-218$

Sullivan, T.P., Sullivan, D.S., 2008. Vole-feeding damage and forest plantation protection: large-scale application of diversionary food to reduce damage to newly planted trees. Crop Prot. 27, 775-784.

Sutherland D., 2003. Fossorial rodent control compositions and methods. U.S Patent number 6, 558, 684 B1.

Tovee, M.J., 1995. Ultra-violet photoreceptors in the animal kingdom: their distribution and function. Trends Ecol. Evol. 10, 455-460. 
Tupper, S.K., Werner, S.J., Carlson, J.C., Pettit, S.E., Wise, J.C., Lindell, C.A., Linz, G.M., 2014. European starling feeding activity on repellent treated crops and pellets. Crop Prot. 63, 76-82.

Werner, S.J., Provenza, F.D., 2011. Reconciling sensory cues and varied consequences of avian repellents. Physiol. Behav. 102, 158-163.

Werner, S.J., Carlson, J.C., Tupper, S.K., Santer, M.M., Linz, G.M., 2009. Threshold concentrations of an anthraquinone-based repellent for Canada geese, red-winged blackbirds, and ring-necked pheasants. Appl. Anim. Behav. Sci. 121, 190-196.

Werner, S.J., Linz, G.M., Tupper, S.K., Carlson, J.C., 2010. Laboratory efficacy of chemical repellents for reducing blackbird damage in rice and sunflower crops. J. Wildl. Manage. 74, 1400-1404.

Werner, S.J., Linz, G.M., Carlson, J.C., Pettit, S.E., Tupper, S.K., Santer, M.M., 2011a. Anthraquinone-based bird repellent for sunflower crops. Appl. Anim. Behav. Sci. 129, 162-169.

Werner, S.J., Tupper, S.K., Pettit, S.E., Carlson, J.C., Linz, G.M., 2011b. Anthraquinone repellent to reduce take of non-target birds from zinc phosphide rodenticide applications. Appl. Anim. Behav. Sci. 135, 146-153.

Werner, S.J., Tupper, S.K., Carlson, J.C., Pettit, S.E., Ellis, J.W., Linz, G.M., 2012. The role of a generalized ultraviolet cue for blackbird food selection. Physiol. Behav. 106, 597-601.

Werner, S.J., Buchholz, R., Tupper, S.K., Pettit, S.E., Ellis, J.W., 2014a. Functional significance of ultraviolet feeding cues in wild turkeys. Physiol. Behav. 123, 162-167.
Werner, S.J., DeLiberto, S.T., Pettit, S.E., Mangan, A.M., 2014b. Synergistic effect of an ultraviolet feeding cue for an avian repellent and protection of agricultural crops. Appl. Anim. Behav. Sci. 159, 107-113.

Werner, S.J., Tupper, S.K., Pettit, S.E., Ellis, J.W., Carlson, J.C., Goldade, D.A., Hofmann, N.M., Homan, H.J., Linz, G.M., 2014c. Application strategies for an anthraquinone-based repellent to protect oilseed sunflower crops from pest blackbirds. Crop Prot. 59, 63-70.

Werner, S.J., DeLiberto, S.T., Mangan, A.M., Pettit, S.E., Ellis, J.W., Carlson, J.C., 2015 Anthraquinone-based repellent for horned larks, great-tailed grackles, American crows and the protection of California's specialty crops. Crop Prot. 72, 158-162.

Werner, S.J., 2015. Ultraviolet strategy for avian repellency. Patent 9, 131, 678. U.S. Patent and Trademark Office, Alexandria, Virginia.

Williams, S.C., Short, M.R., 2014. Evaluation of eight repellents in deterring eastern cottontail herbivory in Connecticut. Hum. Wildl. Interact. 8, 113-122.

Witmer, G.W., Moulton, R.S., 2012. Deer mice (Peromyscus spp.) biology: damage and management: a review. Proc. Vertebr. Pest Conf. 25, 213-219.

Witmer, G.W., Singleton, G., 2010. Sustained agriculture: the need to manage rodent damage in: Agricultural Production Wager, F.C., Ed. pp. 1-38.

Witmer, G.W., Sayler, R., Huggins, D., Capelli, J., 2007. Ecology and management of rodents in no-till agriculture in Washington, USA. Integr. Zool. 2, 154-164. 